\title{
Role of the hypothalamic-pituitary-adrenal axis, glucocorticoids and glucocorticoid receptors in toxic sequelae of exposure to bacterial and viral products
}

\author{
Jeanette I Webster and Esther M Sternberg \\ Section on Neuroendocrine Immunology and Behavior, National Institute of Mental Health, National Institutes of Health, Department of Health and Human \\ Services, Bethesda, Maryland 20892, USA \\ (Requests for offprints should be addressed to Esther M Sternberg, Section on Neuroendocrine Immunology and Behavior, National Institute of Mental Health, \\ National Institutes of Health, Bldg 36, Rm. 1A23, 36 Convent Drive, MSC 4020, Bethesda, Maryland 20892-4020, USA; Email: sternbee@mail.nih.gov)
}

\begin{abstract}
The hypothalamic-pituitary-adrenal (HPA) axis is activated during many bacterial and viral infections, resulting in an increase in circulating glucocorticoid levels. This HPA axis activation and glucocorticoid response are critical for the survival of the host, as demonstrated by the fact that removal of the HPA axis (by adrenalectomy or hypophysectomy) or glucocorticoid receptor (GR) blockade enhances the severity of the infection and in some
\end{abstract}

cases enhances the mortality rate. Replacement with a synthetic glucocorticoid reverses these effects by reducing the severity of the infection and provides protection against lethal effects. In addition, some bacteria and viral infections have been shown to affect the GR directly. These have been described and the implications of such an effect discussed.

Journal of Endocrinology (2004) 181, 207-221

\section{Introduction}

Upon bacterial or viral infection, a cascade of events, termed the 'acute phase response', is initiated. These include inflammation at the local site and, systemically, fever, leukocytosis, hormone release and other pathways, which all function to restore the host homeostasis that has been disturbed by the infection. These pathways elicit signaling mechanisms, most notably cytokines, which mediate these responses. Macrophages at the site of infection are one of the most important cell types in initiating this acute phase response. For more in-depth reviews on the mechanisms and pathways induced by infections leading to the acute phase response refer to the reviews by Biron (1994), Koj (1996) and Van Amersfoort et al. (2003).

Undoubtedly, the release of glucocorticoids has many effects on bacterial and viral infection and on the immunity induced by these infectious agents. It is also well known that hypothalamic-pituitary-adrenal (HPA) axis activation - for example, by stress - can enhance the susceptibility to infectious disease. For example, HPA axis activation enhances Mycobacterium bovis growth in susceptible mice (Brown et al. 1993, Brown \& Zwilling 1994) and increases susceptibility to viral disease (Glaser \& Kiecolt-Glaser 1998, Rozlog et al. 1999). Moreover, glucocorticoids enhance the replication of some viruses.
However, these effects are not the focus of this review; we will concentrate purely on the effects of these infections on the HPA axis and glucocorticoid responses. For more information on the effect of HPA axis activation and glucocorticoids on bacterial and viral infections and the acute phase response, see the reviews by Berczi (1993, 1998), Pearce et al. (2001) and Bailey et al. (2003).

\section{HPA axis}

A bidirectional communication exists between the brain and immune systems, in which the immune system signals the brain via cytokines (Mulla \& Buckingham 1999), and the brain responds by regulating the immune system, in part through the action of the HPA axis with resultant release of glucocorticoids (Webster et al. 2002). Other central nervous system (CNS) response pathways, including the sympathetic and parasympathetic and peripheral nervous systems, also play a role; however, these are not the focus of this review (for a detailed review, see Elenkov et al. (2000)). Upon either inflammatory, physical or psychosocial stimulation, the cells of the paraventricular nucleus of the hypothalamus express corticotropinreleasing hormone $(\mathrm{CRH})$ in the hypophyseal blood supply. This, in turn, stimulates the anterior pituitary 


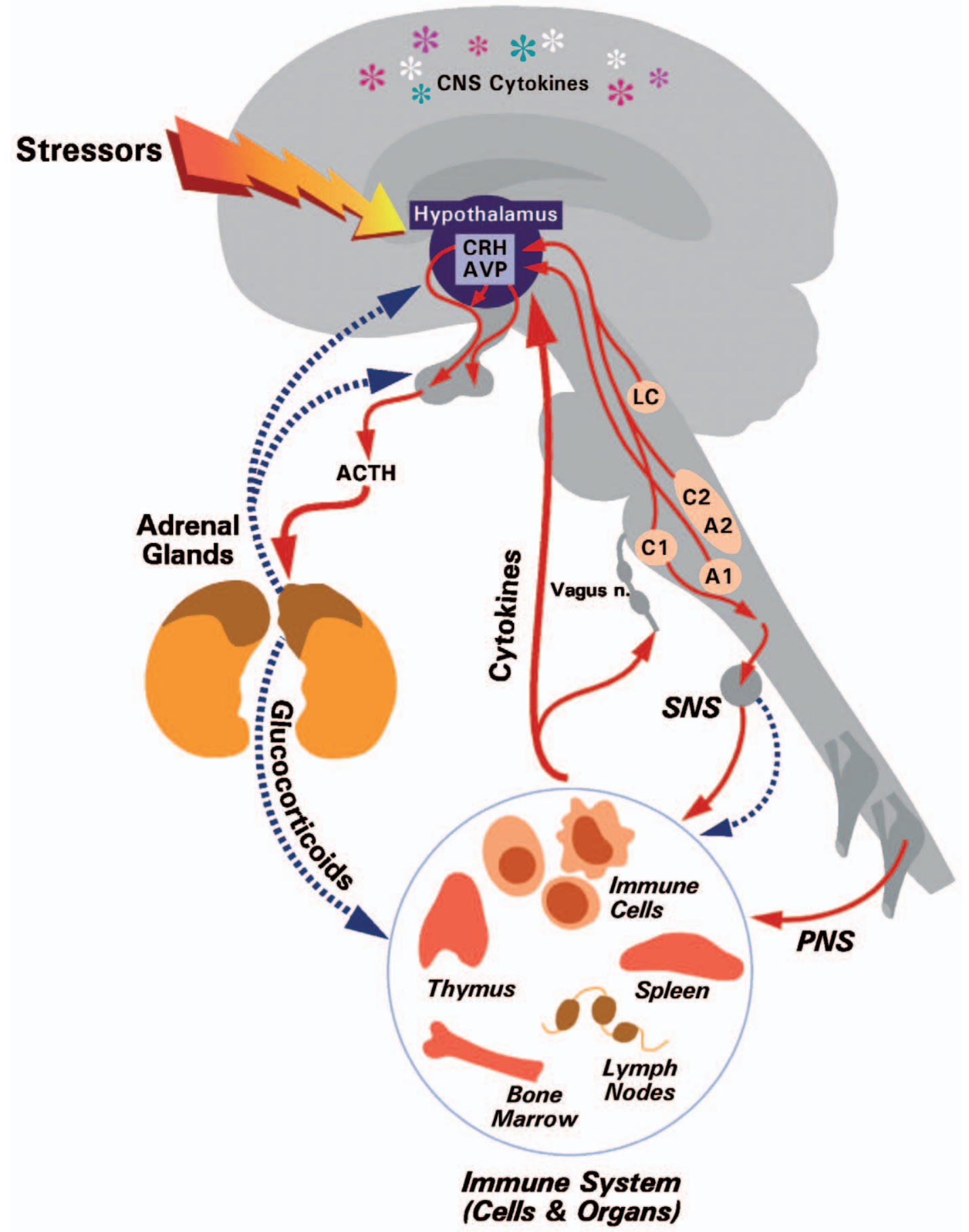

Figure 1 The hypothalamic-pituitary-adrenal (HPA) axis. Dotted lines represent negative regulatory pathways, solid lines represent positive regulatory pathways. Reprinted with permission from Annual Review of Immunology, Volume 20 (C) 2002 by Annual Reviews (www.annualreviews.org). CRH, corticotrophin releasing hormone; AVN, arginine vasopressin; ACTH, adrenocorticotrophin hormone; SNS, sympathetic nervous system; PNS parasympathetic nervous system. 


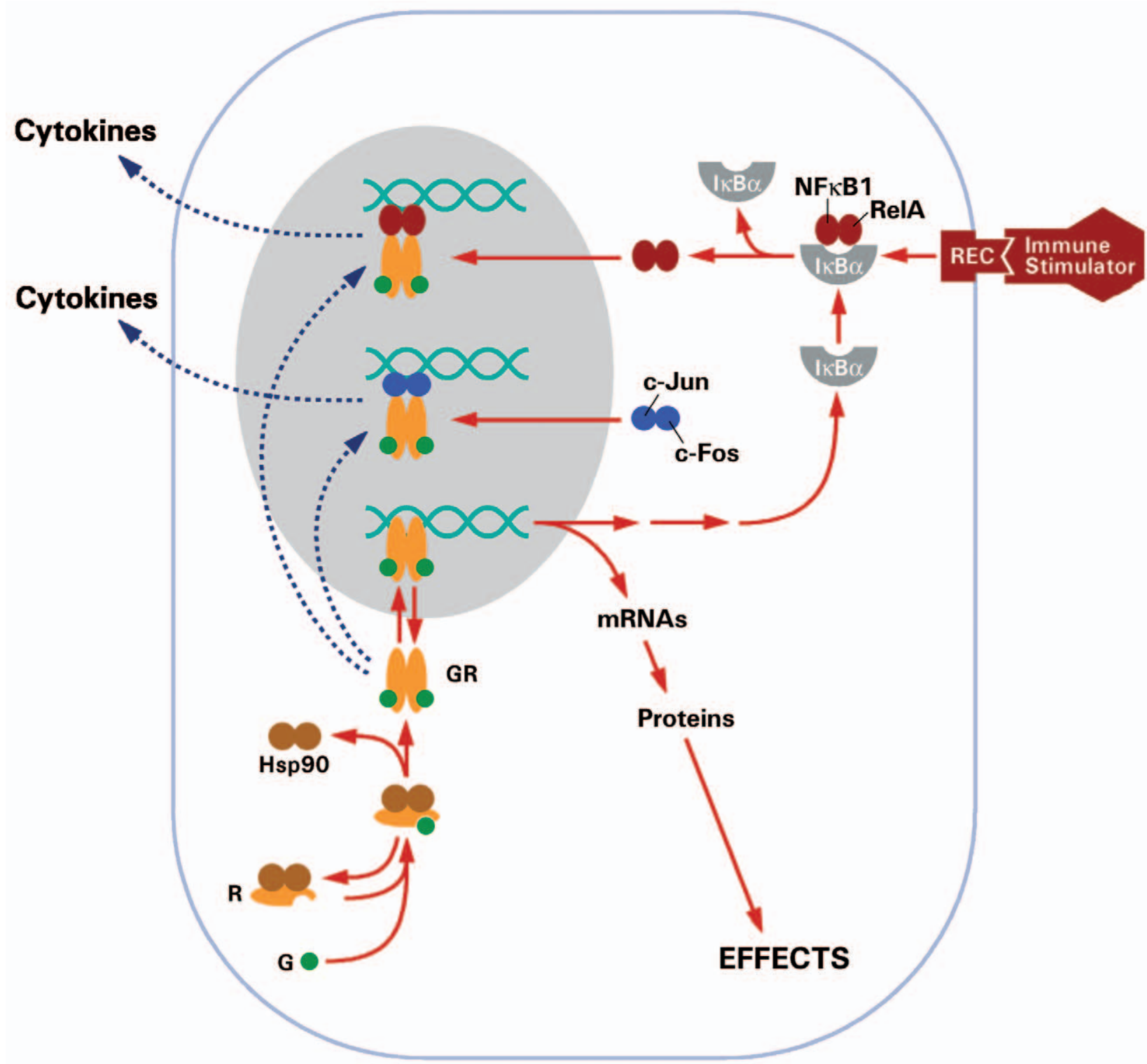

Figure 2 Schematic diagram illustrating the mechanism of action of the glucocorticoid receptor (GR). Dotted lines represent negative regulatory pathways. Reprinted with permission from Annual Review of Immunology, Volume 20 (C) 2002 by Annual Reviews (www.annualreviews.org).

gland to release adrenocorticotropin hormone $(\mathrm{ACTH})$ into the bloodstream. At the adrenals, ACTH stimulates the synthesis and release of glucocorticoids. This axis is self-regulated, with glucocorticoids feeding back to the hypothalamus and pituitary to downregulate the HPA axis (Fig. 1). Cortisol is the endogenous glucocorticoid in man; in rodents, it is corticosterone. Regulation of the immune system is not the only function of glucocorticoids. They are also essential for the regulation of several homeostatic mechanisms in the body, including the CNS, cardiovascular system and metabolic homeostasis. The precise mechanism by which glucocorticoids regulate the immune system will not be discussed here in detail, but it has been the subject of another recent review (Webster et al. 2002).

\section{Glucocorticoid receptor (GR)}

Glucocorticoids exert their many effects through a cytosolic receptor, the glucocorticoid receptor (GR), a member of the nuclear hormone receptor superfamily, which also includes the thyroid hormone, mineralocorti- 
Table 1 Bacterial and viral infections that activate the HPA axis

Bacterial

LPS

Endotoxin

Mycoplasma fermentans

Clostridium difficile toxin A

Shiga toxin 2

Tetanus toxoid

Staphylococcal enterotoxin A

Staphylococcal enterotoxin B
Viral

Murine cytomegalovirus (MCMV)

Lymphocytic choriomeningitis virus (LCMV)

Poly (I:C)

HIV

Herpes simplex virus type 1 (HSV-1)

Sindbis virus

Newcastle disease virus (NDV)

Influenza virus coid, estrogen and progesterone receptors (Evans 1988). In the absence of the ligand, GR is located in the cytoplasm in a protein complex that includes Hsp90 and Hsp70. Upon activation by binding of its ligand, GR is released from the protein complex, dimerizes, and translocates to the nucleus, where it binds to specific DNA sequences called glucocorticoid response elements (GRE) (Fig. 2). Thus, GR functions as a ligand-dependent transcription factor (Aranda \& Pascual 2001). GR is able to upregulate gene expression through direct DNA binding; for example, it binds to the gluconeogenic enzyme tyrosine aminotransferase (TAT), whose promoter contains a consensus GRE sequence (Jantzen et al. 1987). GR can also bind to negative GREs (nGRE) to repress gene activation, such as for the pro-opiomelanocortin (POMC) gene (Drouin et al. 1989). However, GR can also repress gene transcription by interfering with the action of other signaling pathways, such as nuclear factor kappa $\mathrm{B}$ (NFKB) and activator protein-1 (AP-1) (Fig. 2), and it is through this mechanism that glucocorticoids exert many of their anti-inflammatory actions (McKay \& Cidlowski 1999, Adcock 2000). The importance of GR is emphasized by the fact that lack of GR is incompatible with life, and GR knockout mice die shortly after birth due to a defect in lung maturation (Cole et al. 1995). However, it appears that the anti-inflammatory actions of GR associated with its ability to interfere with other signaling mechanisms may be the most critical for survival. Dimerization knockout mice $\left(\mathrm{GR}^{\mathrm{dim} / \mathrm{dim}}\right)$, in which GRE-mediated gene activation, which is entirely dependent on GR dimerization, is removed but GR interactions with NFKB and AP-1, which are independent of dimerization, are still possible, are viable (Reichardt et al. 1998).

\section{Activation of the HPA axis during bacterial or viral infection}

Many bacterial and viral infections result in an activation of the HPA axis and increased glucocorticoid release (Table 1). This activation of the HPA axis is probably the result of the action of inflammatory mediators such as cytokines. In some cases, the inflammatory mediators have been identified. However, it is also possible, if the infections are located in the hypothalamus, that these infections could have a direct effect on the HPA axis. Some of these are described below.

\section{Bacterial HPA axis activation}

Endotoxins, lipopolysaccharides (LPS) from the outer membrane of Gram-negative bacteria, mediate many of the peripheral and brain responses caused by the bacteria (Van Amersfoort et al. 2003). In animals, injection of endotoxin or LPS activates the HPA axis and increases plasma ACTH and corticosterone levels (Butler et al. 1989, Feuerstein et al. 1990, Ramachandra et al. 1992, Schotanus et al. 1994, Ma et al. 2000). Similarly, in humans, HPA axis responses are increased during endotoxemia (Vedder et al. 1999). This increase is influenced by the diurnal glucocorticoid cycle, enhanced HPA axis responses to endotoxin occurs when endogenous glucocorticoid levels are lowest (Pollmacher et al. 1996). The bacterium Mycoplasma fermentans also causes an increase in serum ACTH and corticosterone (Weidenfeld et al. 1995).

Bacterial proteins have also been shown to activate the HPA axis. Clostridium difficile toxin A increases plasma corticosterone levels in Wistar rats and in C57BL/6J mice (Castagliuolo et al. 2001, Mykoniatis et al. 2003). It is thought that this toxin activates the HPA axis through inflammatory mediators, such as tumor necrosis factor $\alpha$ $(\mathrm{TNF} \alpha)$ and prostaglandin $\mathrm{E}_{2}\left(\mathrm{PGE}_{2}\right)$, which are released prior to corticosterone induction following injection into rodent intestine (Castagliuolo et al. 1997). Shiga toxin 2 also induces increased plasma corticosterone levels in $\mathrm{BALB} / \mathrm{c}$ mice (Gomez et al. 2003), and the tetanus toxoid increases cortisol and ACTH levels following vaccination in volunteers (Catania et al. 1990, Oken et al. 1998).

The bacterial superantigen Staphylococcus aureus enterotoxin B (SEB), but not SEA, stimulates the HPA axis with increased plasma corticosterone and $\mathrm{ACTH}$, and even increased c-fos expression (a marker for neuronal activation) and increased CRH mRNA in the hypothalamus in BALB/c mice (Shurin et al. 1997, Kusnecov et al. 1999, 
Goehler et al. 2001). This SEB activation of the HPA axis is dependent on $\mathrm{T}$ cells but independent of macrophages (Shurin et al. 1997). However, SEA, but not SEB, activates the HPA axis in C57BL/6 mice with increases in corticosterone and ACTH. This differential HPA axis activation by these superantigens is dependent on the type of $\mathrm{T}$ cells in these mice strains (Kawashima \& Kusnecov 2002). A repertoire of $T$ cells exists due to gene splicing. The $V \beta$ region of the T-cell receptor is coded by up to 20 different genes, and the V $\beta$ gene utilized can be used to differentiate $T$ cells. SEA preferentially activates $V \beta 3^{+} \mathrm{T}$ cells whereas SEB activates T cells with the V $\beta 8$ motif. $\mathrm{C} 57 \mathrm{BL} / 6$ mice have a prominent $\mathrm{V} \beta 3^{+} \mathrm{T}$-cell repertoire whereas $\mathrm{BALB} / \mathrm{c}$ mice lack $\mathrm{V} \beta 3^{+} \mathrm{T}$ cells (Takimoto et al. 1990, Shurin et al. 1997).

\section{Viral HPA axis activation}

Some viral infections activate the HPA axis, inducing an increase in glucocorticoid release. The kinetics of glucocorticoid release is both virus-specific and specific to the phase of the response, and is also influenced by the route of exposure. The murine cytomegalovirus (MCMV) (Price et al. 1996, Ruzek et al. 1997, Pearce et al. 2001), lymphocytic choriomeningitis virus (LCMV) (Miller et al. 1997, Pearce et al. 2001) and poly (I:C) (a synthetic viral analog) induced increases in glucocorticoid levels (Ruzek et al. 1997, Pearce et al. 2001). Furthermore, MCMV virus and poly (I:C) have been shown to induce glucocorticoid release through an interleukin (IL)-6-dependent pathway (Ruzek et al. 1997).

Patients with HIV infection are known to exhibit a glucocorticoid hypersensitive state with increased plasma glucocorticoid levels (Christeff et al. 1997). In an animal model for retrovirus-induced immunodeficiency, an increase in ACTH and corticosterone was observed, beginning only 3 months after infection (Espey \& Basile 1999). Expression of the HIV protein pg120 in the brain, as is often seen in AIDS patients, increases CRH, ACTH and cortisol levels (Raber et al. 1996, Costa et al. 2000).

Corneal inoculation of minute amounts of herpes simplex virus type 1 (HSV-1) results in nervous system and brainstem replication of the virus without disease symptoms. During this asymptomatic infection, an acute increase in ACTH and corticosterone levels is observed over 14 days, but it returns to basal by 4 weeks after inoculation (Ben-Hur et al. 1995). Similarly, purified viral proteins inoculated intracerebroventricularly (ICV) also induce an acute increase in ACTH and corticosterone expression. This HSV-1 induction of the HPA axis is dependent on brain IL-1 and circulating glucocorticoids, since either ICV injected IL-1 receptor antagonist or adrenalectomy completely abolished this HSV-1 induction of ACTH and corticosterone (Ben-Hur et al. 2001b). Other viruses that have been shown to activate the HPA axis include the
Sindbis virus (Trgovcich et al. 1997), Newcastle disease virus (NDV) (Dunn et al. 1987a,b, Besedovsky \& del Rey 1989, Dunn \& Vickers 1994) and the influenza virus (Dunn et al. 1989, Hermann et al. 1994).

The mechanism by which bacterial and viral infections activate the HPA axis will not be fully discussed in this review. However, it should be mentioned that cytokines are considered to be the mediators of such viral and bacterial-induced glucocorticoid release. Cytokine release and HPA axis activation during a bacterial or viral infection are far more complicated than during administration of a single cytokine or purified bacterial product such as LPS (Biron 1994). IL-6 has been shown to be the primary mediator of glucocorticoid release following MCMV infection (Ruzek et al. 1997). Some viruses, including poly (I:C), are IL-6 specific (Pearce et al. 2001) whereas NDV glucocorticoid release is IL-1 dependent (Dunn \& Vickers 1994). Additional cytokine interactions are probably also involved. For example, IL-2 and TNF synergize to enhance glucocorticoid release following LCMV E350 infection in IL-12-treated mice (Orange et al. 1995). The role of cytokines in activation of the HPA axis by bacterial endotoxin (Berczi 1993, Tilders et al. 1994, Beishuizen \& Thijs 2003) and by viral infection (Pearce et al. 2001, Bailey et al. 2003) has been extensively reviewed by others and will not be further discussed here.

It is worth remembering that, although bacterial and viral infections do have effects on the HPA axis and glucocorticoid release, pain, psychological stress and the debilitating effects of infection also activate the HPA axis and cause glucocorticoid release, thereby complicating the pattern and causes of glucocorticoid release during infection.

\section{Direct adrenal glucocorticoid release following bacterial or viral infection}

Glucocorticoid release from the adrenal glands is typically thought to be under the control of the HPA axis. However, glucocorticoid release from the adrenals is also controlled by neural (catecholaminergic and peptidergic) pathways and directly by the immune system through cytokine stimulation (for a review, see Bornstein \& Chrousos (1999)). The increased glucocorticoid level induced during MCMV virus infection is not mediated only through the HPA axis, since MCMV infection in CRH-deficient mice has no effect on ACTH but is still able to induce glucocorticoid release, whereas in wild-type mice this infection induces both ACTH and CRH. This suggests that although MCMV infection stimulates the HPA axis, it may also have secondary direct effects on the adrenal glands to stimulate glucocorticoid release (Pearce et al. 2001). LPS was also shown to increase plasma corticosterone in hypophysectomized rats (Suzuki et al. 1986, Mazzocchi et al. 1995). In one study, endotoxin effects on ACTH appeared to be independent of $\mathrm{CRH}$ 
Table 2 Interruption of HPA axis and glucocorticoid responses in increased mortality or severity of bacterial and viral infections and the role of exogenous glucocorticoid in protection

Effect of HPA axis blockade

\section{Organism}

Endotoxin/LPS
Increased mortality or fever
Effect of glucocorticoid treatment

Reduced mortality or fever
Reference
E. coli

Clostridium difficile toxin A

Shiga toxin

Staphylococcus aureus enterotoxin B (SEB)

MCMV virus
Increased mortality

Increased inflammation

Increased mortality and disease symptoms

Increased mortality

Increased mortality
Reduced mortality

Reduced inflammation

Reduced mortality

Reduced mortality

Reduced mortality
Jeffries \& Wilkins 1973, McCallum \& Stith 1982, Lazar \& Agarwal 1986, Nakano et al. 1987, Butler et al. 1989, Sternberg et al. 1989,

Edwards et al. 1991, Coelho et al. 1992, Hawes et al. 1992, Lazar et al. 1992b, 1995, Ramachandra et al. 1992, Morrow et al. 1993, Silverstein et al. 1993, McClellan et al. 1994

Silverstein \& Johnson 2003

Castagliuolo et al. 2001, Mykoniatis et al. 2003

Palermo et al. 2000, Gomez et al. 2003

Gonzalo et al. 1993

Price et al. 1996, Ruzek et al. 1999 expression, as paraventricular nucleus lesions did not greatly affect endotoxin effects on ACTH or corticosterone, suggesting a direct effect on the pituitary (Elenkov et al. 1992). In another study, high-dose endotoxin appeared to have direct effects on the adrenals, since an anti-CRH antibody had minimal effect on corticosterone but abolished ACTH responses, whereas low-dose endotoxin functioned purely though the classical HPA axis (Schotanus et al. 1994). In addition, LPS has been shown to stimulate cortisol release directly from the human adrenocortical cell line H295R (Vakharia et al. 2002). NDV also induced corticosterone release in hypophysectomized mice, suggesting a direct induction of corticosterone from immune mediators, the so-called lymphoid-adrenal axis (Smith et al. 1982). However, these results could not be repeated by others (Dunn et al. 1987a,b, Dunn \& Vickers 1994), and another study found no evidence of an ACTH-like immunoreactive substance (Besedovsky \& del Rey 1989). The reason for this discrepancy is unclear.

\section{Role of an intact HPA axis and glucocorticoid responses in protecting against bacterial and viral insults}

Natural and synthetic glucocorticoids protect against the lethal effects of many bacterial and viral components. These are summarized in Table 2.

\section{Bacterial endotoxin}

It has long been known that for glucocorticoids to protect against endotoxin lethality they must be administered either before or concurrent with the endotoxin challenge (Geller et al. 1954). After endotoxin, they are ineffective (Geller et al. 1954). Agents that activate the HPA axis and cause concurrent glucocorticoid release, such as hydrazine sulfate, have also been shown to protect against endotoxin lethality (Silverstein et al. 1989, 1991).

In contrast, agents that block the HPA axis, as in pretreatment with GR antagonists (pregnenolone $16 \alpha$ carbonitrile (PCN) or mifepristone (RU486)) or metyrapone (an inhibitor of glucocorticoid synthesis), enhance LPS and endotoxin lethality and LPS-induced fever (Jeffries \& Wilkins 1973, Lazar \& Agarwal 1986, Sternberg et al. 1989, Hawes et al. 1992, Lazar et al. 1992b, 1995, Ramachandra et al. 1992, Silverstein et al. 1993, McClellan et al. 1994). Even the normally endotoxinnonresponsive $\mathrm{C} 3 \mathrm{H} / \mathrm{HeJ}$ mice could be made endotoxin sensitive by RU486 (Lazar \& Agarwal 1986, Lazar et al. $1992 b, 1995)$. This effect, including the C3H/HeJ mice, can be reversed by concurrent treatment with glucocorticoids (cortisone or dexamethasone) (Jeffries \& Wilkins 1973, Lazar \& Agarwal 1986, Hawes et al. 1992, Lazar et al. 1992b, 1995, Ramachandra et al. 1992). Likewise, removal of endogenous glucocorticoids by adrenalectomy significantly enhances the lethality of endotoxin or LPS (McCallum \& Stith 1982, Nakano et al. 1987, Butler et al. 1989, Coelho et al. 1992, Morrow et al. 1993, Silverstein et al. 1993). This mortality can be reversed by administration of dexamethasone, but not by the natural glucocorticoids, corticosterone and deoxycorticosterone, suggesting that synthetic glucocorticoids are more effective than the endogenous glucocorticoids in protecting against endotoxin/LPS lethality in adrenalectomized animals (Butler et al. 1989, Silverstein et al. 1993). In one study, $10 \mathrm{mg} / \mathrm{kg}$ dexamethasone was effective in preventing 
$50 \mu \mathrm{g}$ LPS toxicity in adrenalectomized BALB/c mice, whereas $10 \mathrm{mg} / \mathrm{kg}$ corticosterone was ineffective (Butler et al. 1989). In another study, $500 \mu \mathrm{g}$ dexamethasone prevented $50 \mu \mathrm{g}$ LPS toxicity in adrenalectomized CF1 mice, whereas a combination of $400 \mu \mathrm{g}$ corticosterone and $200 \mu \mathrm{g}$ deoxycorticosterone was ineffective. However, this combination of corticosterone and deoxycorticosterone was able partially to prevent toxicity from $10-20 \mu \mathrm{g}$ LPS (Silverstein et al. 1993). Surgical interruption of the HPA axis at other levels, such as hypophysectomy, also increases mortality from shock. Thus, mortality rates from Salmonella typhimurium endotoxin or LPS are increased in hypophysectomized rodents (Butler et al. 1989, Edwards et al. 1991, Silverstein et al. 1993). This LPS/endotoxin-induced mortality upon removal of endogenous glucocorticoids or HPA axis blockade most likely occurs as a result of increased cytokine production, particularly TNFa (Butler et al. 1989, Lazar et al. 1992a). Such increases in cytokine levels (TNF $\alpha$ and IL-6) following LPS/endotoxin administration are also seen in HPA axis blockade (adrenalectomy or RU486), and these can be reversed by glucocorticoid treatment (Hawes et al. 1992, Morrow et al. 1993).

The importance of glucocorticoids in modulating endotoxin effects has also been shown in humans by IV injection of endotoxin to healthy men at different time points during the circadian cycle. Those receiving the endotoxin in the evening, when endogenous glucocorticoids are low, showed more severe temperature and plasma ACTH and cortisol changes than those receiving the endotoxin in the morning when glucocorticoid levels are the highest (Pollmacher et al. 1996). Finally, the requirement for an intact glucocorticoid response for survival from endotoxin is further demonstrated by the fact that GR overexpression in mice renders them resistant to LPS-induced endotoxin shock (Reichardt et al. 2000).

\section{Live bacteria}

Although much research has focused on bacterial endotoxins or purified products such as LPS, some research has focused on live bacteria. In these experiments, the effects of adrenalectomy in enhancing mortality and the protective efficacy of dexamethasone in preventing this effect vary with bacterial strain and type. Thus, as in those studies described above, adrenalectomy enhanced lethality from Gram-negative bacteria, such as E. coli, and this could be reversed by dexamethasone treatment (Silverstein \& Johnson 2003). However, dexamethasone treatment did not prevent the mildly enhanced lethality from the Grampositive bacterium $S$. aureus in adrenalectomized animals (Silverstein \& Johnson 2003). In a D-galactosamine mouse model of septic shock, dexamethasone prevented lethality in all 10 Gram-negative strains tested but in only three (Enterococcus faecalis) of the 11 Gram-positive strains tested (Papasian et al. 2002).
Antibiotic treatment concomitant with dexamethasone treatment is more effective than dexamethasone treatment alone for treatment of shock resulting from exposure to live bacteria (Pitcairn et al. 1975. Hinshaw et al. 1981, 1985). For example, antibiotics in combination with dexamethasone protect against $S$. aureus whereas dexamethasone alone was ineffective (Silverstein et al. 2000, Silverstein \& Johnson 2003). This difference between dexamethasone alone and dexamethasone in conjunction with antibiotic treatment is probably due to the release of bacterial products during antibiotic bacterial death, which in some cases may induce a different cytokine pattern (Cui et al. 2000, 2003, Silverstein et al. 2000).

\section{Bacterial toxins}

HPA axis blockade shows effects on shock responses similar to those of bacterial toxins. Thus, removal of endogenous glucocorticoid responses by the GR antagonist RU486 or by adrenalectomy results in enhanced C. difficile toxin A-induced fluid secretion and inflammation (Castagliuolo et al. 2001, Mykoniatis et al. 2003). Similarly, adrenalectomy enhances time to lethality in Shiga toxin 2-injected $\mathrm{BALB} / \mathrm{c}$ mice and also increases the pathologic effects of this toxin, as seen by increased serum urea levels and histopathology (Gomez et al. 2003). Likewise, adrenalectomy or RU486 increases the lethality of normally nonlethal doses of the bacterial superantigen SEB in BALB/c mice (Gonzalo et al. 1993).

These enhanced inflammatory responses in adrenalectomized animals can be reversed by dexamethasone administration or by corticosterone replacement. Replacement with a physiological corticosterone dose results in an inflammatory response equivalent to sham-operated animals while replacement of high pharmacologic corticosterone dose results in a reduction of the inflammatory response (Castagliuolo et al. 2001). Similarly, endogenous induction of glucocorticoid by HPA axis stimulation also reduces the mortality from shock. Survival rates of $\mathrm{BALB} / \mathrm{c}$ mice from Shiga toxin 2 were enhanced by 18-h pretreatment of either LPS or dexamethasone whereas only $1 \mathrm{~h}$ of LPS pretreatment decreased survival rates. This protection afforded by the $18 \mathrm{~h}$ LPS pretreatment condition was shown to be due to the increased endogenous corticosterone production secondary to LPS-induced IL-1 $\beta$ activation of the HPA axis (Palermo et al. 2000). In these studies, the role of endogenous glucocorticoids in protection against Shiga toxin lethality was further supported by the decreased survival of adrenalectomized animals or those treated with the GR antagonist RU486. Furthermore, dexamethasone treatment reversed the increased mortality in adrenalectomized animals (Gomez et al. 2003). Likewise, administration of exogenous dexamethasone protected adrenalectomized $\mathrm{BALB} / \mathrm{c}$ mice 
Table 3 Bacteria that interact with the glucocorticoid receptor (GR)

Effect

Bacteria/bacterial product
Endotoxin

Endotoxin

Chlamydia pneumoniae
Superantigen SEB
Shiga toxin 2
Anthrax lethal toxin

Dex, dexamethasone.

Reference

GR downregulation

Downregulation of leukocyte GR number Inhibition of Dex binding (rat liver nuclei) Inhibition of Dex binding (peritoneal macrophages) Increased GR number, reduced affinity (bronchial epithelial cells)

Activation of GR

Induction of GR $\beta$

Increased GR expression

Repression of GR activity
McCallum \& Stith 1982, Stith \& McCallum 1983 Li \& Xu 1988 Vaptzarova et al. 1989 Jiayi \& Chen 1992

Verheggen et al. 1996

Gencay et al. 2003

Hauk et al. 2000

Gomez et al. 2003

Webster et al. 2003 from bacterial superantigen SEB lethality (Gonzalo et al. 1993).

\section{Viral infections}

Interruption of the HPA axis and glucocorticoid replacement has also been shown to alter mortality from viral infection. These effects are both host- and virus straindependent. Adrenalectomy has been shown to increase the mortality from MCMV infection in C57BL/6 mice, and this mortality could be reversed by glucocorticoid treatment. This increased mortality following adrenalectomy was correlated with increases in levels of the cytokines IFN $\gamma$, TNF and IL-6 (Ruzek et al. 1999). In another study, adrenalectomy of BALB/c, but not C57BL/6, mice increased the mortality rates from MCMV virus (Price et al. 1996). In the study by Price et al. $4 \times 10^{4} \mathrm{pfu}$ (plaque-forming units) MCMV virus was used, and $85 \%$ of the adrenalectomized C57BL/6 mice survived (Price et al. 1996). However, in the study by Ruzek et al. (1999), when a viral load similar to that used by Price et al. $\left(5 \times 10^{4}\right.$ pfu MCMV virus) was used, approximately $70 \%$ of the C57BL/ 6 adrenalectomized mice survived, while a higher viral load $\left(1 \times 10^{5}\right.$ pfu MCMV virus) was fatal. Thus, there appears to be a differential sensitivity in these two strains, independent of corticosterone production, to the lethality of MCMV virus.

In some cases, data indicate that circulating glucocorticoids are essential for expression of symptoms of viral infection. Thus, intracerebral inoculation of HSV-1 causes symptoms of fever, motor hyperactivity and aggressive behavior in rats. Adrenalectomy prevented HSV-1 induction of all these symptoms, and hypophysectomy or RU486 prevented HSV-1 induced fever. However, neither adrenalectomy, hypophysectomy nor RU486 affected mortality rates. Dexamethasone restored these HSV-1-induced symptoms in these adrenalectomized animals (Ben-Hur et al. 2001a).
In summary, while the effect is dependent on the specific pathogen, its dose and the strain of animal infected, in most cases, interruption of the HPA axis by adrenalectomy, hypophysectomy, inhibition of glucocorticoid synthesis or use of a GR antagonist enhances bacterial or viral toxicity or severity of disease. These effects can be reversed by glucocorticoid administration (Table 2). These data emphasize the critical role the HPA axis and glucocorticoid responses play in modulating host responses to infection and the necessity of such responses for survival.

\section{Direct effects of bacterial or viral proteins on the GR}

Some bacteria and viruses or their proteins have a direct effect on the GR, either on the activity or the number of receptor molecules. A list of the interactions by bacteria is shown in Table 3 and by viruses in Table 4.

\section{Effect of endotoxin on $G R$}

Glucocorticoids play an important role in glucose metabolism and, in particular, affect some of the key enzymes in gluconeogenesis. Endotoxins induce changes in glucose metabolism, with an initial hyperglycemic state with increased plasma glucose levels being followed by a hypoglycemic state with deceased plasma glucose levels before death (McCallum et al. 1983, Stith \& McCallum 1988). Adrenalectomized mice do not exhibit the initial hyperglycemia but show a more pronounced hypoglycemic state (McCallum et al. 1983) and a reduced endotoxin $\mathrm{LD}_{50}$ (McCallum \& Stith 1982). Endotoxins also reduce liver glycogen levels (McCallum \& Berry 1973) and the activity of several gluconeogenic enzymes, including the rate-limiting enzyme phosphoenolpyruvate kinase (PEPCK) (McCallum et al. 1983, Stith \& McCallum 
Table 4 Viruses that interact with the glucocorticoid receptor (GR)

\section{Effect}

Virus/viral product

HIV (Vpr)

Poxvirus MC protein MC013L

Influenza virus

HSV-1

Epstein-Barr virus

MCMV
Enhances GR activity (acts as cofactor)

Inhibits GR activity

Increases GR activity

Increases GR number and activity

Increases GR number

Decreases GR binding in spleen
Reference

Kino et al. 1999, 2002

Sherman et al. 2000

Chen et al. 2000

Ghoshal et al. 2001

Erlandsson et al. 2002

Tomita et al. 1985

Miller et al. 1997
1988), glycogen synthase (Giger \& McCallum 1976), fructose-1,6-diphosphatase and glucose-6-phosphatase (McCallum \& Berry 1972). Neither dexamethasone nor glucagon increased plasma glucose levels in endotoxintreated mice (Stith \& McCallum 1983, 1988).

The effects of endotoxin on GR ligand binding has been studied, since PEPCK and other gluconeogeneic enzymes are enhanced by dexamethasone through induction of gene transcription by the GR. Stith \& McCallum $(1982,1983)$ showed that endotoxin downregulated liver GR numbers. In ligand-binding studies, endotoxin reduced the Bmax (maximum number of binding sites) 3-6 h after injection of $100 \mu \mathrm{g}$ LPS but had no effect on association or dissociation rates, or on the equilibrium dissociation constant $\left(K_{\mathrm{d}}\right)$. They showed that endotoxin reduced GR numbers in other tissues, including liver, kidney, skeletal muscle, spleen, lung and heart, but had no effect on PEPCK activity in kidney or glycogen content in skeletal muscle (Stith \& McCallum 1986). In radioligand competition studies, endotoxin did not directly compete with $\left[{ }^{3} \mathrm{H}\right]$ dexamethasone for binding and so did not directly affect GR (Stith \& McCallum 1983). Additional studies have also shown an effect of endotoxin on GR. In dogs treated with endotoxin, an endotoxin-induced downregulation of leukocyte GR numbers, as assayed by $\left[{ }^{3} \mathrm{H}\right]$ dexamethasone binding, was also observed ( $\mathrm{Li} \& \mathrm{Xu}$ 1988). Endotoxin inhibition of $\left[{ }^{3} \mathrm{H}\right]$ dexamethasone binding was also seen in rat liver nuclei (Vaptzarova et al. 1989) and peritoneal macrophages (Jiayi \& Chen 1992). In bronchial epithelial cells, LPS caused an increase in GR number but also reduced the ligand affinity, as seen by an increase in the $K_{\mathrm{d}}$ (Verheggen et al. 1996). However, others could find no effect of endotoxin on GR numbers (Shackleford et al. 1986).

Some studies have attempted to determine how endotoxin downregulates GR numbers. A soluble factor released from macrophages following endotoxin treatment has been reported to account for endotoxin downregulation of GRs (Hill et al. 1987). This factor was termed 'glucocorticoid antagonizing factor' (GAF) and was shown to reduce liver glycogen levels (Sakaguchi et al. 1990) and inhibit PEPCK activity (Goodrum \& Berry 1978, 1979). Purification showed it to be a $90 \mathrm{kDa}$ glycoprotein (Sakaguchi \& Yokota 1987). Although the exact components of GAF have never been fully identified, it does show some similarities to TNF $\alpha$ (Moore et al. 1978), and cytokines, including IL-1 and TNF $\alpha$, are also released from macrophages following endotoxin (Koj 1996, Van Amersfoort et al. 2003). IL-1 and TNFa have also been shown to repress glucocorticoid induction of the gluconeogenic enzyme PEPCK (Hill et al. 1986, 1988, Hill \& McCallum 1992), and IL-1 and IL-6 downregulate GR numbers (Hill et al. 1986, 1988, Stith et al. 1989) in a similar way to endotoxin. Whether GAF is a cytokine or not has not been determined, and, interestingly, there has been no mention of GAF in the scientific literature since 1990. More recently, interest has focused on the glucocorticoid counter-regulator, macrophage migration inhibitor factor (MIF) (Baugh \& Bucala 2002). A monoclonal antibody against MIF has been shown to protect against septic shock induced by cecal ligation and puncture (CLP) and E. coli peritonitis (Calandra et al. 2000, Roger et al. 2001), whereas IP injection of recombinant MIF enhanced the lethality of E. coli peritonitis (Calandra et al. 2000).

\section{Effect of other bacteria and bacterial proteins on GR}

Chlamydia pneumoniae infection of epithelial cells leads to activation of GR, as determined by nuclear translocation, DNA binding and induction of the GR-inducible gene $\mathrm{p} 21^{\text {(Waf1/Cip1) }}$, and this activation can be inhibited by RU486. GR activation leads to increased host cell proliferation, which again can be inhibited by RU486. Thus, in this system, activation of GR ensures the survival and propagation of the infected host cells (Gencay et al. 2003). In human peripheral blood mononuclear cells (PBMCs), the bacterial superantigen SEB induces glucocorticoid resistance in $\mathrm{T}$ cells by increasing the expression of the proposed dominant negative GR isoform, GR $\beta$ (Hauk et al. 2000). 
Shiga toxin 2 has been shown to increase GR expression, as determined by fluorescence activated cell sorting (FACS) analysis, $24 \mathrm{~h}$ after injection, and this is sustained through $48 \mathrm{~h}$. However, the implications of this are not clear, particularly as dexamethasone is not protective at $24 \mathrm{~h}$ after injection (Gomez et al. 2003). We have recently shown that the anthrax lethal toxin represses GR activity as well as the activity of other nuclear hormone receptors and inhibits the glucocorticoid increase in the liver gluconeogenic enzyme, tyrosine aminotransferase. Although the precise mechanism of this repression is not yet fully understood, it does not occur by direct competition with ligand or DNA binding, and may involve one of the many cofactors necessary for GR effects on transcription (Webster et al. 2003).

\section{Effect of viral proteins on $G R$}

As in the case of bacterial products, viral proteins also interact with GR, and the specific effects of viruses are strain dependent. It has long been realized that many of the symptoms associated with AIDS are similar to those associated with excess glucocorticoid production. In fact, AIDS patients do exhibit a glucocorticoid-hypersensitive state. Recently, it has been shown that one of the HIV-1 accessory proteins, Vpr, can function as a GR coactivator (Kino et al. 1999, Sherman et al. 2000). This protein contains the consensus LXXLL nuclear receptor signature motif and can bind directly to GR (Kino et al. 1999) to function as an adaptor protein enabling interaction between GR and cofactors such as p300 (Kino et al. 2002). This interaction has been shown to affect GR functionally, as extracellularly administered $\mathrm{Vpr}$ can enhance dexamethasone suppression of IL-12 in PMBCs (Mirani et al. 2002). In addition, Vpr has been shown to interact with the viral protein, $\mathrm{R}$ interacting protein 1 (Rip-1), and both Rip-1 and Vpr can be co-immunoprecipitated with GR as part of the activated receptor complex (Refaeli et al. 1995). Vpr action as a GR cofactor requires an intact GRE and is dependent on the ligand and the presence of the receptor, but is independent of cell-cycle arrest (Sherman et al. 2000), as has been suggested by others (Forget et al. 1998). In addition, GR affinity can vary in patients with AIDS, with some expressing normal affinity GR and others low-affinity receptors (Norbiato et al. 1997).

MC013 L, a protein from the poxvirus molluscum contagiosum (MC), has recently been shown to inhibit GR- and vitamin D (VDR)-mediated gene transactivation, but not retinoid- or estrogen-mediated gene transactivation. Direct interaction between the MC013 L protein and GR and VDR has been shown. This GR and VDR repression has been suggested to promote virus replication by preventing the differentiation of the infected keratinocytes (Chen et al. 2000). The influenza virus also increases GR activity. The expression of the GRregulated genes, metallothionein I (MT-I) and II (MT-II), is induced by the influenza virus. This effect can be repressed by RU486, suggesting a direct role for GR in viral induction of these proteins. In addition, influenza virus has been shown to enhance GR binding to the promoter of these genes (Ghoshal et al. 2001).

HSV-1 virus upregulates GR number and increases GR nuclear translocation of GR in human primary gingival fibroblasts. This increase in GR translocation is accompanied by an increase in GR transactivation, as indicated by the fact that HSV-1 virus can induce gene transcription from a GR-controlled reporter construct in HEK 293 cells (Erlandsson et al. 2002). Transformation of human lymphocytes with Epstein-Barr virus also increases GR number without affecting $K_{\mathrm{d}}$ (Tomita et al. 1985). In contrast, MCMV virus infection has also been shown to decrease GR binding in the spleen (Miller et al. 1997).

\section{Septic shock}

An animal model of septic shock has been developed with a murine model of septic peritonitis using cecal ligation just below the iliocecal valve followed by puncture with a 20-21 gauge needle (CLP). The rate of survival was dependant on the gauge of the needle used, survival rates being greater with the smaller needle. Plasma corticosterone levels are similarly elevated in both CLP and sham operated rats following polymicrobial sepsis, but the CLP operated animals showed enhanced ACTH levels compared with sham operated animals, suggesting adrenal insufficiency (Koo et al. 2001). This model has been used to support the role of endotoxins in septic shock, since LPS-tolerant mice showed higher survival rates than LPS-sensitive mice (Lazar et al. 1992b, 1995). Administration of RU486 decreased the survival rates following cecal puncture (Lazar et al. 1992b).

Since it is generally older patients who develop lethal endotoxic shock, the effect of endotoxin in older animals has been investigated. Older mice have a reduced $\mathrm{LD}_{50}$ to LPS even though they have a large increase in plasma corticosterone levels following a low dose of LPS $(1 \mathrm{mg} /$ $\mathrm{kg}$ ) compared with younger mice, which have only a small increase in plasma corticosterone following this dose of LPS. Thus, it appears that their increase in corticosterone is insufficient to protect against a large increase in TNF $\alpha$ and nitric oxide (NO) levels (Chorinchath et al. 1996). Age-related differences in GR signaling following endotoxin challenge have also been reported in older mice in which plasma corticosterone levels were similar to younger mice. However, increased $\left[{ }^{3} \mathrm{H}\right]$ dexamethasone binding without increased gluconeogenic enzyme activity, such as that of PEPCK, was shown in these older mice, suggesting some degree of glucocorticoid resistance (Stith \& McCallum 1985).

From the animal data presented above and the effectiveness of glucocorticoids in inflammation, one might 
expect that glucocorticoids would be an effective treatment for septic shock. However, the use of glucocorticoids in the treatment of septic shock has been a matter of controversy since the 1950s. In some instances they have been shown to enhance survival rates, but in others they have been shown to enhance mortality. The pros and cons of glucocorticoid therapy have recently been reviewed in detail (Balk 2003, Sessler 2003), and will not be reviewed here. However, it is generally now accepted that high doses of glucocorticoids are not effective in the treatment of septic shock while controversy still exists about the effectiveness of physiological doses.

It is worth noting that glucocorticoid levels are increased in humans during critical illness and septic shock (Vermes et al. 1995). During the acute phase of critical illness, the increased glucocorticoid release is correlated with increased ACTH levels (Vermes et al. 1995). However, during the chronic phase of sepsis, there is a dissociation between ACTH and cortisol levels, ACTH being low while cortisol levels are still high (Siegel et al. 1994, Vermes et al. 1995); this suggests that the sustained disease state can have a non-ACTH-mediated effect on cortisol release (Bornstein \& Chrousos 1999). During a prolonged critical illness or sepsis, there is evidence that there is, in fact, adrenal insufficiency despite the patient's exhibiting normal or elevated glucocorticoid levels (Sibbald et al. 1977, Rothwell et al. 1991, Williamson \& Lapointe 2003). It has been reported that $25-40 \%$ of septic shock patients have adrenal insufficiency (Soni et al. 1995, Koo et al. 2001, Marik \& Zaloga 2003). It is also possible that there are differences in glucocorticoid sensitivity at the level of the receptor during septic shock. In one study, enhanced sensitivity of peripheral leukocytes to glucocorticoids has been noted (Molijn et al. 1995b). In another study, a decreased affinity was noted (Molijn et al. 1995a). Therefore the use of glucocorticoids in the treatment of septic shock may be dependent on the stage of the sepsis, the reactivity of the HPA axis, particularly the adrenals, and the sensitivity of GR to the ligand. Taken together these variables make the effects of the therapeutic use of glucocorticoids in septic shock difficult to predict.

\section{Conclusions}

Many bacterial and viral infections result in an activation of the HPA axis and resultant release of glucocorticoids. This can either occur centrally at the level of the hypothalamus or pituitary or through direct activation of the adrenal glands. The HPA axis activation and resultant glucocorticoid release following bacterial or viral infections are advantageous to both the infectious agent and the host. HPA axis activation can be advantageous to the invading organism, as it serves to minimize the host immune responses, thereby enhancing the organism's ability to survive. However, enhanced glucocorticoid release that generally suppresses immune system responses prevents overreactivity of the immune system with associated release of dangerous levels of cytokines, such as TNFa. In this manner, HPA axis activation is involved in regulatory feedback control of the acute phase response to an infection, which serves, through mechanisms not discussed here, to restore the homeostasis of the host.

Indeed, an intact HPA axis and resultant glucocorticoid release are necessary for host survival after exposure to an infectious agent. It has now been shown in numerous viral and bacterial infections that interruption of the HPA axis, by hypophysectomy, adrenalectomy, inhibition of glucocorticoid synthesis or the use of the GR antagonist RU486, can enhance the severity or lethality of the infection, and that replacement with glucocorticoids can prevent these effects.

Some bacteria and viral products also have direct effects on the GR. In the case of those that upregulate either GR numbers or GR activity, there is an obvious evolutionary advantage to the pathogen, since increased GR functioning would be expected to have a greater suppressive effect on the host immune system thereby promoting survival of the bacteria or virus. For example, C. pneumoniae increases GR activation, resulting in survival of host infected cells, and the MC poxvirus protein MC013 L inhibits GR, thereby preventing differentiation of the infected keratinocytes, and allowing virus replication. Bacterial superantigens increase the expression of GR $\beta$, the inactive form of GR. For those bacteria and viruses that cause a decrease in GR number or activity, as anthrax lethal toxin does, it is more difficult to see an evolutionary advantage to the invading organism. However, inhibition of GR would be predicted to be detrimental to host survival.

In summary, bacteria and viruses modulate host responses by activating the HPA axis and increasing glucocorticoid levels; in turn, an intact HPA axis and glucocorticoid response are critical to the host survival from inflammatory sequelae of exposure to infectious agents. Such agents can also modulate host responses by directly affecting GR functioning. These effects are organism and host strain specific, and are also dependent on dose. The ultimate lethality of a pathogen thus depends on a complex interplay between the specific organism's induction of an appropriate level of the host's HPA axis response, the intactness of that response and possible direct pathogen interactions at the level of the GR. Precise definitions of these interactions in an individual host exposed to a particular pathogen will be essential to designing effective therapy for shock targeted at HPA axis components.

\section{References}

Adcock IM 2000 Molecular mechanisms of glucocorticosteroid actions. Pulmonary Pharmacology and Therapeutics 13 115-126. 
Aranda A \& Pascual A 2001 Nuclear hormone receptors and gene expression. Physiological Reviews 81 1269-1304.

Bailey M, Engler H, Hunzeker J \& Sheridan JF 2003 The hypothalamic-pituitary-adrenal axis and viral infection. Viral Immunology 16 141-157.

Balk RA 2003 Steroids for septic shock: back from the dead? (pro). Chest 123 490S-499S.

Baugh JA \& Bucala R 2002 Macrophage migration inhibitory factor. Critical Care Medicine 30 S27-S35.

Beishuizen A \& Thijs LG 2003 Endotoxin and the hypothalamopituitary-adrenal (HPA) axis. Journal of Endotoxin Research 9 3-24.

Ben-Hur T, Conforti N, Itzik A \& Weidenfeld J 1995 Effects of HSV-1, a neurotropic virus, on the hypothalamic-pituitaryadrenocortical axis in rats. Brain Research 702 17-22.

Ben-Hur T, Cialic R, Itzik A, Barak O, Yirmiya R \& Weidenfeld J 2001a A novel permissive role for glucocorticoids in induction of febrile and behavioral signs of experimental herpes simplex virus encephalitis. Neuroscience 108 119-127.

Ben-Hur T, Cialic R, Itzik A, Yirmiya R \& Weidenfeld J 2001 b Acute effects of purified and UV-inactivated herpes simplex virus type 1 on the hypothalamo-pituitary-adrenocortical axis. Neuroendocrinology 74 160-166.

Berczi I 1993 Neuroendocrine defense in endotoxin shock. Acta Microbiologica Hungarica 40 265-302.

Berczi I 1998 Neuroendocrine response to endotoxin. Annals of the New York Academy of Sciences 851 411-415.

Besedovsky HO \& del Rey A 1989 Mechanism of virus-induced stimulation of the hypothalamus-pituitary-adrenal axis. Journal of Steroid Biochemistry 34 235-239.

Biron CA 1994 Cytokines in the generation of immune responses to, and resolution of, virus infection. Current Opinions in Immunology 6 530-538.

Bornstein SR \& Chrousos GP 1999 Clinical review 104. Adrenocorticotropin (ACTH)- and non-ACTH-mediated regulation of the adrenal cortex: neural and immune inputs. Journal of Clinical Endocrinology and Metabolism 84 1729-1736.

Brown DH \& Zwilling BS 1994 Activation of the hypothalamicpituitary-adrenal axis differentially affects the anti-mycobacterial activity of macrophages from BCG-resistant and susceptible mice. Journal of Neuroimmunology 53 181-187.

Brown DH, Sheridan J, Pearl D \& Zwilling BS 1993 Regulation of mycobacterial growth by the hypothalamus-pituitary-adrenal axis: differential responses of Mycobacterium bovis BCG-resistant and -susceptible mice. Infection and Immunity 61 4793-4800.

Butler LD, Layman NK, Riedl PE, Cain RL, Shellhaas J, Evans GF \& Zuckerman SH 1989 Neuroendocrine regulation of in vivo cytokine production and effects. I. In vivo regulatory networks involving the neuroendocrine system, interleukin-1 and tumor necrosis factor-alpha. Journal of Neuroimmunology 24 143-153.

Calandra T, Echtenacher B, Roy DL, Pugin J, Metz CN, Hultner L, Heumann D, Mannel D, Bucala R \& Glauser MP 2000 Protection from septic shock by neutralization of macrophage migration inhibitory factor. Nature Medicine 6 164-170.

Castagliuolo I, Kelly CP, Qiu BS, Nikulasson ST, LaMont JT \& Pothoulakis C 1997 IL-11 inhibits Clostridium difficile toxin A enterotoxicity in rat ileum. American Journal of Physiology $\mathbf{2 7 3}$ G333-G341.

Castagliuolo I, Karalis K, Valenick L, Pasha A, Nikulasson S, Wlk M \& Pothoulakis C 2001 Endogenous corticosteroids modulate Clostridium difficile toxin A-induced enteritis in rats. American Journal of Physiology 280 G539-G545.

Catania A, Airaghi L, Manfredi G \& Zanussi C 1990 Hormonal response during antigenic challenge in normal subjects. International Journal of Neuroscience 51 295-296.

Chen N, Baudino T, MacDonald PN, Green M, Kelley WL, Burnett JW \& Buller RM 2000 Selective inhibition of nuclear steroid receptor function by a protein from a human tumorigenic poxvirus. Virology 274 17-25.
Chorinchath BB, Kong LY, Mao L \& McCallum RE 1996 Ageassociated differences in TNF-alpha and nitric oxide production in endotoxic mice. Journal of Immunology 156 1525-1530.

Christeff N, Gherbi N, Mammes O, Dalle MT, Gharakhanian S, Lortholary O, Melchior JC \& Nunez EA 1997 Serum cortisol and DHEA concentrations during HIV infection. Psychoneuroendocrinology 22 (Suppl 1) S11-S18.

Coelho MM, Souza GE \& Pela IR 1992 Endotoxin-induced fever is modulated by endogenous glucocorticoids in rats. American Journal of Physiology 263 R423-R427.

Cole TJ, Blendy JA, Monaghan AP, Krieglstein K, Schmid W, Aguzzi A, Fantuzzi G, Hummler E, Unsicker K \& Schutz G 1995 Targeted disruption of the glucocorticoid receptor gene blocks adrenergic chromaffin cell development and severely retards lung maturation. Genes and Development 9 1608-1621.

Costa A, Nappi RE, Polatti F, Poma A, Grossman AB \& Nappi G 2000 Stimulating effect of HIV-1 coat protein gp120 on corticotropin-releasing hormone and arginine vasopressin in the rat hypothalamus: involvement of nitric oxide. Experimental Neurology 166 376-384.

Cui W, Morrison DC \& Silverstein R 2000 Differential tumor necrosis factor alpha expression and release from peritoneal mouse macrophages in vitro in response to proliferating Gram-positive versus Gram-negative bacteria. Infection and Immunity $\mathbf{6 8}$ 4422-4429.

Cui W, Lei MG, Silverstein R \& Morrison DC 2003 Differential modulation of the induction of inflammatory mediators by antibiotics in mouse macrophages in response to viable Gram-positive and Gram-negative bacteria. Journal of Endotoxin Research 9 225-236.

Drouin J, Sun YL \& Nemer M 1989 Glucocorticoid repression of pro-opiomelanocortin gene transcription. Journal of Steroid Biochemistry 34 63-69.

Dunn AJ \& Vickers SL 1994 Neurochemical and neuroendocrine responses to Newcastle disease virus administration in mice. Brain Research 645 103-112.

Dunn AJ, Powell ML \& Gaskin JM 1987a Virus-induced increases in plasma corticosterone. Science 238 1423-1425.

Dunn AJ, Powell ML, Moreshead WV, Gaskin JM \& Hall NR 1987 b Effects of Newcastle disease virus administration to mice on the metabolism of cerebral biogenic amines, plasma corticosterone, and lymphocyte proliferation. Brain Behavior and Immunity 1 216-230.

Dunn AJ, Powell ML, Meitin C \& Small PA Jr 1989 Virus infection as a stressor: influenza virus elevates plasma concentrations of corticosterone, and brain concentrations of MHPG and tryptophan. Physiology and Behavior 45 591-594.

Edwards CK 3rd, Yunger LM, Lorence RM, Dantzer R \& Kelley KW 1991 The pituitary gland is required for protection against lethal effects of Salmonella typhimurium. PNAS $\mathbf{8 8}$ 2274-2277.

Elenkov IJ, Kovacs K, Kiss J, Bertok L \& Vizi ES 1992 Lipopolysaccharide is able to bypass corticotrophin-releasing factor in affecting plasma ACTH and corticosterone levels: evidence from rats with lesions of the paraventricular nucleus. Journal of Endocrinology 133 231-236.

Elenkov IJ, Wilder RL, Chrousos GP \& Vizi ES 2000 The sympathetic nerve - an integrative interface between two supersystems: the brain and the immune system. Pharmacological Reviews 52 595-638.

Erlandsson AC, Bladh LG, Stierna P, Yucel-Lindberg T, Hammarsten O, Modeer T, Harmenberg J \& Wikstrom AC 2002 Herpes simplex virus type 1 infection and glucocorticoid treatment regulate viral yield, glucocorticoid receptor and NF-kappaB levels. Journal of Endocrinology 175 165-176.

Espey MG \& Basile AS 1999 Glutamate augments retrovirus-induced immunodeficiency through chronic stimulation of the hypothalamic-pituitary-adrenal axis. Journal of Immunology 162 4998-5002. 
Evans RM 1988 The steroid and thyroid hormone receptor superfamily. Science 240 889-895.

Feuerstein G, Hallenbeck JM, Vanatta B, Rabinovici R, Perera PY \& Vogel SN 1990 Effect of Gram-negative endotoxin on levels of serum corticosterone, TNF alpha, circulating blood cells, and the survival of rats. Circulatory Shock 30 265-278.

Forget J, Yao XJ, Mercier J \& Cohen EA 1998 Human immunodeficiency virus type $1 \mathrm{Vpr}$ protein transactivation function: mechanism and identification of domains involved. Journal of Molecular Biology 284 915-923.

Geller P, Merrill ER \& Jawetz E 1954 Effects of cortisone and antibiotics on lethal action of endotoxins in mice. Proceedings of the Society for Experimental Biology and Medicine 86 716-719.

Gencay MM, Tamm M, Glanville A, Perruchoud AP \& Roth M 2003 Chlamydia pneumoniae activates epithelial cell proliferation via $\mathrm{NF}-\mathrm{kappaB}$ and the glucocorticoid receptor. Infection and Immunity 71 5814-5822.

Ghoshal K, Majumder S, Zhu Q, Hunzeker J, Datta J, Shah M, Sheridan JF \& Jacob ST 2001 Influenza virus infection induces metallothionein gene expression in the mouse liver and lung by overlapping but distinct molecular mechanisms. Molecular and Cellular Biology 21 8301-8317.

Giger O \& McCallum RE 1976 Response of mouse liver glycogen cycle enzymes to endotoxin treatment. American Journal of Physiology 231 1285-1289.

Glaser R \& Kiecolt-Glaser JK 1998 Stress-associated immune modulation: relevance to viral infections and chronic fatigue syndrome. American Journal of Medicine 105 35S-42S.

Goehler LE, Gaykema RP, Hansen MK, Kleiner JL, Maier SF \& Watkins LR 2001 Staphylococcal enterotoxin B induces fever, brain c-Fos expression, and serum corticosterone in rats. American Journal of Physiology 280 R1434-R1439.

Gomez SA, Fernandez GC, Vanzulli S, Dran G, Rubel C, Berki T, Isturiz MA \& Palermo MS 2003 Endogenous glucocorticoids attenuate Shiga toxin-2-induced toxicity in a mouse model of haemolytic uraemic syndrome. Clinical and Experimental Immunology $131217-224$

Gonzalo JA, Gonzalez-Garcia A, Martinez C \& Kroemer G 1993 Glucocorticoid-mediated control of the activation and clonal deletion of peripheral $\mathrm{T}$ cells in vivo. Journal of Experimental Medicine 177 1239-1246.

Goodrum KJ \& Berry LJ 1978 The effect of glucocorticoid antagonizing factor on hepatoma cells. Proceedings of the Society for Experimental Biology and Medicine 159 359-363.

Goodrum KJ \& Berry LJ 1979 The use of Reuber hepatoma cells for the study of a lipopolysaccharide-induced macrophage factor: glucocorticoid-antagonizing factor. Laboratory Investigation $\mathbf{4 1}$ 174-181.

Hauk PJ, Hamid QA, Chrousos GP \& Leung DY 2000 Induction of corticosteroid insensitivity in human PBMCs by microbial superantigens. Journal of Allergy and Clinical Immunology 105 $782-787$.

Hawes AS, Rock CS, Keogh CV, Lowry SF \& Calvano SE 1992 In vivo effects of the antiglucocorticoid RU 486 on glucocorticoid and cytokine responses to Escherichia coli endotoxin. Infection and Immunity $602641-2647$.

Hermann G, Tovar CA, Beck FM \& Sheridan JF 1994 Kinetics of glucocorticoid response to restraint stress and/or experimental influenza viral infection in two inbred strains of mice. Journal of Neuroimmunology 49 25-33.

Hill MR \& McCallum RE 1992 Identification of tumor necrosis factor as a transcriptional regulator of the phosphoenolpyruvate carboxykinase gene following endotoxin treatment of mice. Infection and Immunity 60 4040-4050.

Hill MR, Stith RD \& McCallum RE 1986 Interleukin 1: a regulatory role in glucocorticoid-regulated hepatic metabolism. Journal of Immunology 137 858-862.
Hill MR, Stith RD \& McCallum RE 1987 Monokines mediate decreased hepatic glucocorticoid binding in endotoxemia. Journal of Leukocyte Biology 41 236-241.

Hill MR, Stith RD \& McCallum RE 1988 Human recombinant IL-1 alters glucocorticoid receptor function in Reuber hepatoma cells. Journal of Immunology 141 1522-1528.

Hinshaw LB, Beller-Todd BK, Archer LT, Benjamin B, Flournoy DJ, Passey R \& Wilson MF 1981 Effectiveness of steroid/antibiotic treatment in primates administered LD100 Escherichia coli. Annals of Surgery 194 51-56.

Hinshaw LB, Beller BK, Chang AC, Murray CK, Flournoy DJ, Passey RB \& Archer LT 1985 Corticosteroid/antibiotic treatment of adrenalectomized dogs challenged with lethal E. coli. Circulatory Shock 16 265-277.

Jantzen HM, Strahle U, Gloss B, Stewart F, Schmid W, Boshart M, Miksicek R \& Schutz G 1987 Cooperativity of glucocorticoid response elements located far upstream of the tyrosine aminotransferase gene. Cell 49 29-38.

Jeffries CD \& Wilkins J 1973 Effect of exogenous steroids and inhibitors of steroidogenesis on endotoxin shock. Proceedings of the Society for Experimental Biology and Medicine 142 656-659.

Jiayi D \& Chen YZ 1992 LPS-induced decrease of specific binding of $3 \mathrm{H}$-dexamethasone to peritoneal macrophages of C57BL/6 mice. Journal of Receptor Research 12 451-462.

Kawashima N \& Kusnecov AW 2002 Effects of staphylococcal enterotoxin A on pituitary-adrenal activation and neophobic behavior in the C57BL/6 mouse. Journal of Neuroimmunology 123 41-49.

Kino T, Gragerov A, Kopp JB, Stauber RH, Pavlakis GN \& Chrousos GP 1999 The HIV-1 virion-associated protein Vpr is a coactivator of the human glucocorticoid receptor. Journal of Experimental Medicine 189 51-61.

Kino T, Gragerov A, Slobodskaya O, Tsopanomichalou M, Chrousos GP \& Pavlakis GN 2002 Human immunodeficiency virus type 1 (HIV-1) accessory protein $\mathrm{Vpr}$ induces transcription of the HIV-1 and glucocorticoid-responsive promoters by binding directly to p300/CBP coactivators. Journal of Virology 76 9724-9734.

Koj A 1996 Initiation of acute phase response and synthesis of cytokines. Biochimica et Biophysica Acta 1317 84-94.

Koo DJ, Jackman D, Chaudry IH \& Wang P 2001 Adrenal insufficiency during the late stage of polymicrobial sepsis. Critical Care Medicine 29 618-622.

Kusnecov AW, Liang R \& Shurin G 1999 T-lymphocyte activation increases hypothalamic and amygdaloid expression of CRH mRNA and emotional reactivity to novelty. Journal of Neuroscience 19 4533-4543.

Lazar G \& Agarwal MK 1986 The influence of a novel glucocorticoid antagonist on endotoxin lethality in mice strains. Biochemical Medicine and Metabolic Biology 36 70-74.

Lazar G, Lazar G, Jr., Husztik E, Duda E \& Agarwal MK 1995 The influence of antiglucocorticoids on stress and shock. Annals of the New York Academy of Sciences 761 276-295.

Lazar G, Jr., Duda E \& Lazar G 1992a Effect of RU 38486 on TNF production and toxicity. FEBS Letters 308 137-140.

Lazar G, Jr., Lazar G \& Agarwal MK 1992b Modification of septic shock in mice by the antiglucocorticoid RU 38486. Circulatory Shock 36 180-184.

Li F \& Xu RB 1988 Changes in canine leukocyte glucocorticoid receptors during endotoxin shock. Circulatory Shock 26 99-105.

Ma XC, Chen LT, Oliver J, Horvath E \& Phelps CP 2000 Cytokine and adrenal axis responses to endotoxin. Brain Research $\mathbf{8 6 1}$ 135-142.

Marik PE \& Zaloga GP 2003 Adrenal insufficiency during septic shock. Critical Care Medicine 31 141-145.

Mazzocchi G, Rocco S, Malendowicz LK, Rebuffat P \& Nussdorfer GG 1995 Bacterial lipopolysaccharide stimulates glucocorticoid secretion in hypophysectomized rats. Endocrine Research 21 525-536. 
McCallum RE \& Berry LJ 1972 Mouse liver fructose-1, 6-diphosphatase and glucose-6-phosphatase activities after endotoxin poisoning. Infection and Immunity 6 883-885.

McCallum RE \& Berry LJ 1973 Effects of endotoxin on gluconeogenesis, glycogen synthesis, and liver glycogen synthase in mice. Infection and Immunity 7 642-654.

McCallum RE \& Stith RD 1982 Endotoxin-induced inhibition of steroid binding by mouse liver cytosol. Circulatory Shock $\mathbf{9}$ 357-367.

McCallum RE, Seale TW \& Stith RD 1983 Influence of endotoxin treatment on dexamethasone induction of hepatic phosphoenolpyruvate carboxykinase. Infection and Immunity 39 213-219.

McClellan JL, Klir JJ, Morrow LE \& Kluger MJ 1994 Central effects of glucocorticoid receptor antagonist RU-38486 on lipopolysaccharide and stress-induced fever. American Journal of Physiology 267 R705-R711.

McKay LI \& Cidlowski JA 1999 Molecular control of immune/ inflammatory responses: interactions between nuclear factor-kappa B and steroid receptor-signaling pathways. Endocrine Reviews 20 435-459.

Miller AH, Spencer RL, Pearce BD, Pisell TL, Tanapat P, Leung JJ, Dhabhar FS, McEwen BS \& Biron CA 19971996 Curt P.

Richter Award. Effects of viral infection on corticosterone secretion and glucocorticoid receptor binding in immune tissues. Psychoneuroendocrinology 22 455-474.

Mirani M, Elenkov I, Volpi S, Hiroi N, Chrousos GP \& Kino T 2002 HIV-1 protein Vpr suppresses IL-12 production from human monocytes by enhancing glucocorticoid action: potential implications of $\mathrm{Vpr}$ coactivator activity for the innate and cellular immunity deficits observed in HIV-1 infection. Journal of Immunology 169 6361-6368.

Molijn GJ, Koper JW, van Uffelen CJ, de Jong FH, Brinkmann AO, Bruining HA \& Lamberts SW 1995a Temperature-induced down-regulation of the glucocorticoid receptor in peripheral blood mononuclear leucocyte in patients with sepsis or septic shock. Clinical Endocrinology 43 197-203.

Molijn GJ, Spek JJ, van Uffelen JC, de Jong FH, Brinkmann AO, Bruining HA, Lamberts SW \& Koper JW 1995b Differential adaptation of glucocorticoid sensitivity of peripheral blood mononuclear leukocytes in patients with sepsis or septic shock. Journal of Clinical Endocrinology and Metabolism 80 1799-1803.

Moore RN, Goodrum KJ, Couch RE, Jr. \& Berry LJ 1978 Elicitation of endotoxemic effects in $\mathrm{C} 3 \mathrm{H} / \mathrm{HeJ}$ mice with glucocorticoid antagonizing factor and partial characterization of the factor. Infection and Immunity 19 79-86.

Morrow LE, McClellan JL, Conn CA \& Kluger MJ 1993 Glucocorticoids alter fever and IL-6 responses to psychological stress and to lipopolysaccharide. American Journal of Physiology 264 R1010-1016.

Mulla A \& Buckingham JC 1999 Regulation of the hypothalamopituitary-adrenal axis by cytokines. Bailliere's Best Practice Research. Clinical Endocrinology and Metabolism 13 503-521.

Mykoniatis A, Anton PM, Wlk M, Wang CC, Ungsunan L, Bluher S, Venihaki M, Simeonidis S, Zacks J, Zhao D, et al. 2003 Leptin mediates Clostridium difficile toxin A-induced enteritis in mice. Gastroenterology 124 683-691.

Nakano K, Suzuki S \& Oh C 1987 Significance of increased secretion of glucocorticoids in mice and rats injected with bacterial endotoxin. Brain Behavior and Immunity 1 159-172.

Norbiato G, Bevilacqua M, Vago T, Taddei A \& Clerici 1997 Glucocorticoids and the immune function in the human immunodeficiency virus infection: a study in hypercortisolemic and cortisol-resistant patients. Journal of Clinical Endocrinology and Metabolism 82 3260-3263.

Oken E, Kasper DL, Gleason RE \& Adler GK 1998 Tetanus toxoid stimulation of the hypothalamic-pituitary-adrenal axis correlates inversely with the increase in tetanus toxoid antibody titers. Journal of Clinical Endocrinology and Metabolism 83 1691-1696.
Orange JS, Salazar-Mather TP, Opal SM, Spencer RL, Miller AH, McEwen BS \& Biron CA 1995 Mechanism of interleukin 12-mediated toxicities during experimental viral infections: role of tumor necrosis factor and glucocorticoids. Journal of Experimental Medicine 181 901-914.

Palermo M, Alves-Rosa F, Rubel C, Fernandez GC, Fernandez-Alonso G, Alberto F, Rivas M \& Isturiz M 2000 Pretreatment of mice with lipopolysaccharide (LPS) or IL-1 beta exerts dose-dependent opposite effects on Shiga toxin-2 lethality. Clinical and Experimental Immunology 119 77-83.

Papasian CJ, Silverstein R, Gao JJ, Bamberger DM \& Morrison DC 2002 Anomalous role of tumor necrosis factor alpha in experimental enterococcal infection. Infection and Immunity 70 6628-6637.

Pearce BD, Biron CA \& Miller AH 2001 Neuroendocrine-immune interactions during viral infections. Advances in Virus Research 56 469-513.

Pitcairn M, Schuler J, Erve PR, Holtzman S \& Schumer W 1975 Glucocorticoid and antibiotic effect on experimental gram-negative bacteremic shock. Archives of Surgery 110 1012-1015.

Pollmacher T, Mullington J, Korth C, Schreiber W, Hermann D, Orth A, Galanos C \& Holsboer F 1996 Diurnal variations in the human host response to endotoxin. Journal of Infectious Diseases $\mathbf{1 7 4}$ 1040-1045.

Price P, Olver SD, Silich M, Nador TZ, Yerkovich S \& Wilson SG 1996 Adrenalitis and the adrenocortical response of resistant and susceptible mice to acute murine cytomegalovirus infection. European Journal of Clinical Investigation 26 811-819.

Raber J, Toggas SM, Lee S, Bloom FE, Epstein CJ \& Mucke L 1996 Central nervous system expression of HIV-1 Gp120 activates the hypothalamic-pituitary-adrenal axis: evidence for involvement of NMDA receptors and nitric oxide synthase. Virology 226 362-373.

Ramachandra RN, Sehon AH \& Berczi I 1992 Neuro-hormonal host defense in endotoxin shock. Brain Behavior and Immunity 6 157-169.

Refaeli Y, Levy DN \& Weiner DB 1995 The glucocorticoid receptor type II complex is a target of the HIV-1 Vpr gene product. PNAS 92 3621-3625.

Reichardt HM, Kaestner KH, Tuckermann J, Kretz O, Wessely O, Bock R, Gass P, Schmid W, Herrlich P, Angel P, et al. 1998 DNA binding of the glucocorticoid receptor is not essential for survival. Cell 93 531-541.

Reichardt HM, Umland T, Bauer A, Kretz O \& Schutz G 2000 Mice with an increased glucocorticoid receptor gene dosage show enhanced resistance to stress and endotoxic shock. Molecular and Cellular Biology 20 9009-9017.

Roger T, Glauser MP \& Calandra T 2001 Macrophage migration inhibitory factor (MIF) modulates innate immune responses induced by endotoxin and Gram-negative bacteria. Journal of Endotoxin Research 7 456-460.

Rothwell PM, Udwadia ZF \& Lawler PG 1991 Cortisol response to corticotropin and survival in septic shock. Lancet 337 582-583.

Rozlog LA, Kiecolt-Glaser JK, Marucha PT, Sheridan JF \& Glaser R 1999 Stress and immunity: implications for viral disease and wound healing. Journal of Periodontology 70 786-792.

Ruzek MC, Miller AH, Opal SM, Pearce BD \& Biron CA 1997 Characterization of early cytokine responses and an interleukin (IL)-6-dependent pathway of endogenous glucocorticoid induction during murine cytomegalovirus infection. Journal of Experimental Medicine 185 1185-1192.

Ruzek MC, Pearce BD, Miller AH \& Biron CA 1999 Endogenous glucocorticoids protect against cytokine-mediated lethality during viral infection. Journal of Immunology 162 3527-3533.

Sakaguchi S \& Yokota K 1987 Purification and characteristics of glucocorticoid antagonizing factor in endotoxemia. Microbiology and Immunology 31 509-520. 
Sakaguchi S, Ibata H \& Yokota K 1990 Participation of calcium ion on depletion mechanism of liver glycogen by purified glucocorticoid antagonizing factor released in blood during endotoxemia. Microbiology and Immunology 34 985-994.

Schotanus K, Makara GB, Tilders FJ \& Berkenbosch F 1994 ACTH response to a low dose but not a high dose of bacterial endotoxin in rats is completely mediated by corticotropin-releasing hormone. Neuroimmunomodulation 1 300-307.

Sessler CN 2003 Steroids for septic shock: back from the dead? (Con). Chest 123 482S-489S.

Shackleford GM, Hart SF \& Berry LJ 1986 Endotoxin treatment inhibits glucocorticoid induction of hepatic enzymes at a late induction step. American Journal of Physiology 250 E218-E225.

Sherman MP, de Noronha CM, Pearce D \& Greene WC 2000 Human immunodeficiency virus type $1 \mathrm{Vpr}$ contains two leucine-rich helices that mediate glucocorticoid receptor coactivation independently of its effects on $\mathrm{G}(2)$ cell cycle arrest. Journal of Virology 74 8159-8165.

Shurin G, Shanks N, Nelson L, Hoffman G, Huang L \& Kusnecov AW 1997 Hypothalamic-pituitary-adrenal activation by the bacterial superantigen staphylococcal enterotoxin B: role of macrophages and T cells. Neuroendocrinology 65 18-28.

Sibbald WJ, Short A, Cohen MP \& Wilson RF 1977 Variations in adrenocortical responsiveness during severe bacterial infections. Unrecognized adrenocortical insufficiency in severe bacterial infections. Annals of Surgery 186 29-33.

Siegel LM, Grinspoon SK, Garvey GJ \& Bilezikian JP 1994 Sepsis and adrenal function. Trends in Endocrinology and Metabolism 5 324-328.

Silverstein R \& Johnson DC 2003 Endogenous versus exogenous glucocorticoid responses to experimental bacterial sepsis. Journal of Leukocyte Biology 73 417-427.

Silverstein R, Christoffersen CA \& Morrison DC 1989 Modulation of endotoxin lethality in mice by hydrazine sulfate. Infection and Immunity 57 2072-2078.

Silverstein R, Turley BR, Christoffersen CA, Johnson DC \& Morrison DC 1991 Hydrazine sulfate protects D-galactosaminesensitized mice against endotoxin and tumor necrosis factor/ cachectin lethality: evidence of a role for the pituitary. Journal of Experimental Medicine 173 357-365.

Silverstein R, Hannah P \& Johnson DC 1993 Natural adrenocorticosteroids do not restore resistance to endotoxin in the adrenalectomized mouse. Circulatory Shock 41 162-165.

Silverstein R, Wood JG, Xue Q, Norimatsu M, Horn DL \& Morrison DC 2000 Differential host inflammatory responses to viable versus antibiotic-killed bacteria in experimental microbial sepsis. Infection and Immunity 68 2301-2308.

Smith EM, Meyer WJ \& Blalock JE 1982 Virus-induced corticosterone in hypophysectomized mice: a possible lymphoid adrenal axis. Science 218 1311-1312.

Soni A, Pepper GM, Wyrwinski PM, Ramirez NE, Simon R, Pina T, Gruenspan H \& Vaca CE 1995 Adrenal insufficiency occurring during septic shock: incidence, outcome, and relationship to peripheral cytokine levels. American Journal of Medicine $\mathbf{9 8}$ 266-271.

Sternberg EM, Hill JM, Chrousos GP, Kamilaris T, Listwak SJ, Gold PW \& Wilder RL 1989 Inflammatory mediator-induced hypothalamic-pituitary-adrenal axis activation is defective in streptococcal cell wall arthritis-susceptible Lewis rats. PNAS $\mathbf{8 6}$ 2374-2378.

Stith RD \& McCallum RE 1983 Down regulation of hepatic glucocorticoid receptors after endotoxin treatment. Infection and Immunity 40 613-621.

Stith RD \& McCallum RE 1985 Effects of aging and endotoxin on hepatic glucocorticoid action and glucose metabolism in mice. Mechanisms of Ageing and Development 30 73-78.

Stith RD \& McCallum RE 1986 General effect of endotoxin on glucocorticoid receptors in mammalian tissues. Circulatory Shock 18 301-309.
Stith RD \& McCallum RE 1988 Failure of glucagon to induce hepatic phosphoenolpyruvate carboxykinase in endotoxic shock. Circulatory Shock 26 267-272.

Stith RD, McCallum RE \& Hill MR 1989 Effect of interleukin-6/ interferon-beta 2 on glucocorticoid action in rat hepatoma cells. Journal of Steroid Biochemistry 34 479-481.

Suzuki S, Oh C \& Nakano K 1986 Pituitary-dependent and -independent secretion of CS caused by bacterial endotoxin in rats. American Journal of Physiology 250 E470-E474.

Takimoto H, Yoshikai Y, Kishihara K, Matsuzaki G, Kuga H, Otani T \& Nomoto K 1990 Stimulation of all T cells bearing V beta $1, \mathrm{~V}$ beta $3, \mathrm{~V}$ beta 11 and $\mathrm{V}$ beta 12 by staphylococcal enterotoxin A. European Journal of Immunology 20 617-621.

Tilders FJ, DeRijk RH, Van Dam AM, Vincent VA, Schotanus K \& Persoons JH 1994 Activation of the hypothalamus-pituitary-adrenal axis by bacterial endotoxins: routes and intermediate signals. Psychoneuroendocrinology 19 209-232.

Tomita M, Chrousos GP, Brandon DD, Ben-Or S, Foster CM, De Vougn L, Taylor S, Loriaux DL \& Lipsett MB 1985 Glucocorticoid receptors in Epstein-Barr virus-transformed human lymphocytes. Hormone and Metabolic Research 17 674-678.

Trgovcich J, Ryman K, Extrom P, Eldridge JC, Aronson JF \& Johnston RE 1997 Sindbis virus infection of neonatal mice results in a severe stress response. Virology 227 234-238.

Vakharia K, Renshaw D \& Hinson JP 2002 Bacterial lipopolysaccharide directly stimulates cortisol secretion in human adrenal cells. Endocrine Research 28 357-361.

Van Amersfoort ES, Van Berkel TJ \& Kuiper J 2003 Receptors, mediators, and mechanisms involved in bacterial sepsis and septic shock. Clinical Microbiology Reviews 16 379-414.

Vaptzarova KI, Baramova EN \& Popov PG 1989 Endotoxin inhibition of glucocorticoid enzyme induction and in vivo $3 \mathrm{H}$-dexamethasone labelling of rat liver nuclei. International Journal of Biochemistry 21 701-705.

Vedder H, Schreiber W, Yassouridis A, Gudewill S, Galanos C \& Pollmacher T 1999 Dose-dependence of bacterial lipopolysaccharide (LPS) effects on peak response and time course of the immuneendocrine host response in humans. Inflammation Research 48 67-74.

Verheggen MM, van Hal PT, Adriaansen-Soeting PW, Goense BJ, Hoogsteden HC, Brinkmann AO \& Versnel MA 1996 Modulation of glucocorticoid receptor expression in human bronchial epithelial cell lines by IL-1 beta, TNF-alpha and LPS. European Respiratory Journal 9 2036-2043.

Vermes I, Beishuizen A, Hampsink RM \& Haanen C 1995 Dissociation of plasma adrenocorticotropin and cortisol levels in critically ill patients: possible role of endothelin and atrial natriuretic hormone. Journal of Clinical Endocrinology and Metabolism 80 $1238-1242$

Webster JI, Tonelli L \& Sternberg EM 2002 Neuroendocrine regulation of immunity. Annual Review of Immunology 20 125-163.

Webster JI, Tonelli LH, Moayeri M, Simons SS, Jr., Leppla SH \& Sternberg EM 2003 Anthrax lethal factor represses glucocorticoid and progesterone receptor activity. PNAS 100 5706-5711.

Weidenfeld J, Wohlman A \& Gallily R 1995 Mycoplasma fermentans activates the hypothalamo-pituitary adrenal axis in the rat. Neuroreport 6 910-912.

Williamson DR \& Lapointe M 2003 The hypothalamic-pituitaryadrenal axis and low-dose glucocorticoids in the treatment of septic shock. Pharmacotherapy 23 514-525.

Received 12 December 2003

Accepted 23 January 2004

Made available online as an

Accepted Preprint 29 January 2004 